\title{
Citizen Journalism As Representation of Local Wisdom In The Modern Information Society
}

\author{
Ida Nuraini Dewi K.N \\ lecturer at Departement of Communication, Universitas Islam Indonesia. \\ email: idadewi23@gmail.com)
}

\begin{abstract}
ABSTRAK
Paper ini membahas tentang persepsi journalisme warga yang merepresentasikan kerarifan lokal dalam mayarakat informasi modern melalui metode kualitatif. Pengumpulan data responden dilakukan melalui gabungan dari dua tahap yakni fokus group dan wawancara mendalam. Paper ini kemudian dianalisis dengan beberapa teori dan konsep tentang jurnalisme warga sebagai bagian dari kegiatan "akar rumput" sampai pada perkembangannya sebagai bagian dari kegiatan jurnalisme yang mengedukasi warganya sendiri. Hasil dari paper ini menunjukkan bahwa beberapa orang menganggap bahwa jurnalisme warga masih menjadi "bagian abu-abu" daam bentuk jurnalisme baru, hal ini dikarenakan cara pengumpulannya yang masih diperdebatkan. Kedua sebagian juga menganggap bahwa sebenarnya jurnalisme warga bisa menjadi salah satu aktivitas positif yang mampu membawa informasi atau berita jauh dari kepentingan pemilik modal. Dan ketiga,masyarakat memandang bahwa jurnalisme warga merupakan bagian baru dalam kegiatan jurnalisme modern yang akan mampu mempertahankan kearifan lokal jika kegiatan ini dilakukan dengan baik.
\end{abstract}

Kata kunci: jurnalisme warga, persepsi, kerifan lokal

\begin{abstract}
This research discusses about the perception of citizen journalism as a representation of local wisdom in the modern information society by using qualitative method. The data are collected by focus group discussion and indepth interview. It analyzed by some theories of citizen journalism as a grassroots voice and some other concepts on how citizen journalism raised in the modern society until the discussion of how it can create a new way of local society educate its own people. The finding shows that, first, some people still perceived that citizen journalism is "a grey" part of new journalism because of the way of it is colleted. The second is some people said that citizen journalism can be alternative media information that brings local context far from the capital interest, which people think that it is a positive activity somehow. The last is that citizen journalism is part of activity which can educate its people and conserves the local wisdom by let its society involved in this activiy.
\end{abstract}

Keywords: citizen journalism, perception, local wisdom 


\section{Introduction}

Nowadays technology brings people to the era in which information are needed in every second of its life. People has tendency to know each matter and happening either in their local environment or in the other places. Therefore, the information flows in current era is faster than before, for example we can know in seconds about the boom attached in US in this lates days (September 2016) or the Tsunami in Aceh, Indonesia (December, 2004) and tsunami in Japan (March, 2011). The unique model of these information production are they had been made and been contributted by the people who are eyewithneses or the poeple who are in the place where it happened.

News as we know before that is something that produced and disseminated by professional journalist, now it has tendency to be change for its definition. As (Dewi, Ida 2013 cited from Takahashi (2010, p.27): "people are not only become audience, but they can also be potential sources and witnesses of event as well as reporters, explained that the role of people who use the media and send information across the time and space are regarded as active." Dewi (2013: 18) also said that the nowadays information that tend to become news made by the contribution of ordinary citizen, using their own cam-coder, cell phone or any other equipment.
Eventhough these new definition are is still argued by some schoolars but in fact the people are doing the same works as professional jouralist does. By their own ability, people also docummented and shared the happening that they had seen or heard by capturing, recording or writing through their smart phone to others. Murdoch (as cited by Stuart Allan, 2006, p.5) later explains that nowadays people should realize that the next generation is accessing news and information with the different expectation-where, how, when and from whom they get it. The information technology brings people to the rapid flow of information era. As it is also explain by Haryanto (2002: 3 ) that nowadays news definition is changed. The previous definition was talked that news is an information that is reported after it is happened, but nowadays as the technology changed, news definition is about reporting an information that might be still occuring and happening.

Moreover Haryanto (2002) said that the modern era and the exsistance of smartphone was bring people to grap and share information easily. It invites people or citizens to participate on creating, producing, and disseminating news and information. Citizen journalism as the terms that accommodate those activities also become a current discussable issue. Some people said that it is because of the accuracy that still lack on its news, but some others argue that it has so much more beneficial in the current democratic 
informative society. We could not say that citizen journalism is all about "hoax" reportage because some people who really and seriously works on it, do made and even can share unpredictable and unreachable report. As we can see some examples above, majority those report are had been reported by the citizen who are whitnesses of the happening. They could report something "big" to others and help mainstream media as contributor to distribute it to others. In some cases, some of them has tendency to write in the social media and it quickly spread to the audience.

The arising of citizen journalism also a kind of reaction of the people to mainstream media which is sometimes discussble as the one who are no longer represent the interests of the people. This reaction then develop as the technology answered the situation. Technology allows people to raise issues that represent their interests, with the aim of voicing their opinions and even can also develop their local culture by share it to others. This is another uniqueness of citizen journlism, it also might be content a local wisdom that may be lack on the reportage of maintream media does. By this paper, the writer want to discuss more about the potential of citizen journalism as representation of local wisdom in this modern information society.

The definition of citizen journalism had been discuss after its arising in these couples years. Some scholars explain that the raising of citizen journalism is because of the developing of technology, let say for "internet" caused. The easier access of information that offers and supports by internet considered as a result of the emergence of citizen journalism. For example "OhmyNews" in 2000 is regarded as a battering ram revival of citizen journalism. This stems from a site that provides space for public expression to voice information, the site then became something that dicussable among people and scholars to the action of citizens in participating and dissemination of information.

In contrast to the rise of citizen journalism in Indonesia, as Kurniawan (2007: 77) explain that journalism in Indonesia was started by the radio program which was onair in 2000, it is called "Elshinta". Elhsinta launched citizen journalism program, aiming to open their line to their listeners. The Elshinta's listeners were welcomed to share information on any event or incident they know to the radio by phone. According to Pacific Media Watch (24 April, 2003 as cited by Dewi 2013:9), the number of their listeners arose from 800,000 in 2001 to 1.2 million in 2002. Moreover Kurniawan explained that it successly gain 100,000 of its audiences to be its citizen journalists. It is different from OhmyNews which only gain 40,000 citizen journalists as its begining (2007: 77). He added that the Elshinta's successfull is because of the 
arosen of the telephone using in Indonesia. At that time, Indonesian people are in an era which telephone and cellular phone are become a popular communication medium. It is the techonological gap between Indonesia and South Korea, while South Korea already common with the use of internet, Indonesia are in the time when cellular phone are becoming a "modern" one.

The issue of citizen participation become a contradiction among scholars and public. Some scholars assume that it can not be called "citizen journalism" because, they perceive that journalism is bounded with etics. As Astraatmadja (2011 was cited by Istiyanto) explains that "citizen journalism is not a proper term, because a journalism is about an activity which should be meet the rules of journalism and professional journalism standart, such as: factual, accuracy, and objective. It should only be called citizen expression"

Contrast to the Nasaruddin (2009: 65), he argued that citizen journalism is an activity which is not produce or created by professional jorunalist. It creates by the citizen which shared to others. Moreover Nasaruddin said that this definition is a kind of special definition in a way of how citizen activity and participacy on producing and diseminating of information. Inline to Nasaruddin, Nuruddin (2009) also mention that citizen journalism is a participacy of the people or citizen--them who is seeing without education background, and skill ability of how they could make a plan, discover, explore, create and diseminating information (writing, picture, photograph, and oral expression).

Inevintably, this debate is still carry citizen journalism paticipation to the information diseminating in the nowadays society. It is an alternative information among the mainstream media information which is can be called as an independent one. As we know that the tendency on the press of mainstream media in Indonesia now are kind of merger of some big institutions which are possible in producing the same ideology of creating news and information. Hachen in Dewi (2015:2) argues that democratic society without independent news media is impossible to imagine. This is an answer of what Kusumaningrat's (2006: 15) fear about "how the democratic society stand still whithout no body telling and sharing news." Therefore, citizen journalism can be defined as a part of democratic people activities on selecting, producing and sharing information to others.

Athough there are some arguments about the definition of citizen journalism, it is now exist in the life of information society. People nowadays can produce and share anything to others. Though these activities, we know that each society brings a unique part to differenciate of each journalism era, as now in the infomation 
era, people say that everyone could be a reporter. This term was arisen from YeungHo, the head of OhmyNews who said in 2004 (in Kurniawan 2007) that "every citizen is a reporter."

The nowadays uniqueness in journalism era is that news now can be produced by even an amateur person. As written above that citizen journalism is a participation of the people who are not seeing by how they are having or not ability to journalism, but on how they want to produce and share information to other. Actually, if I could say this is the basic part of journalism. As we know that journalism is an activity of sharing and documenting the information. The origin word is journal, it is taken from diurnalis (Kusumaningrat 2006: 15)-the Greek word which means daily or each day. So that, it is kind of documenting activities about the daily happens, and nowadays people have a great opportunity on how they document and share the information that they know to others.

Technology brings them to the era that everything is "easy" to be shared. An easy and fast access to internet become kind of invitation to people to sharing as much as possible of information they have to society. As we can see now, by the emerge of social media, now we are flooded by many information, in which we could find from the "silly" updating status information to the unique or an unpredictable information which could not be produced by mainstream media. For example the amateur video information of the fallen military aircraft in Yogyakarta, Indonesia (2016). On that day, mainstream media only could reported the happening after the aircraft was felt down. They could not give an visual description of how it was falling, but citizen did. By the social media, we could saw how the visualization of the aircraft was falling down at that day. It was recorded by the citizen and then he uploaded to the social media.

The activities of audience sharing information in this era is part of their life of society. As previous time we called people who consume the media is "audience" but it no more can not be called. It is because of the opportunity of sharing and participation which is offer by social media and internet medium in this information era. This also effected by the nowadays situation that the audience now can be participate as a community of viewers as well as producer-term of "users". By developing of technology, the people tends to be more expressive. This is kind of new way of journalism, in which the societies' expression can helped the diseminating information in many ways. Sometimes information society can also drive any kinds of movement which named as citizen movement (as a plural audience). For example, the story of Florence-a named of student who stay at Yogyakarta. She could make the city residents angry and wanted her to leave the city. This is because she had to share her status on the page Path to 
offend and insult the city of Yogyakarta as a uncultured, poor and stupid city. This occurs when there is a shortage of fuel in the city so that makes long queues. At that time, Florence decided to charge the bike in the car queue, but then hundreds of bikers cheered, seeing action of that girl who did not want the queue. It was worst after Florence then uploded that ststus to the Path.

The opportunity of sharing also offers citizen to voice the interests on their region or locality. It giving people an opportunity to share and speak about their localities. This is sometimes overlooked by the mainstream news media which are forgetting to the interests of local communities voiced. However, with the ease of public expression then pushed them to defend and maintain their local wisdom by participating on producing and diseminating their local information. As this also noted in the Declarations of Human Rights that everyone has right of seek, receive, and create ideas through ranging from basic movements and utterences of human body in local contexts to sophisticated manipulations of high technology of global communications (Lull, 2007: 27).

Meanwhile, in return, the local wisdom could be develope and exist among this era. Eventhough there are many access and ways of people to adopt other's cultural (western culture) in this era, local wisdom can be exist if the people perceive that they have something unique and should be maintaince or voiced. By citizen participation on producing and creating local information, it can be a kind of citizen journalism which represent the local wisdom.

Local wisdom is about the local ideas which contain of wisdom, positive values, which is embedded and followed people (Istiyanto, 2012: 137). Moreover it also expains by Keraf (in Eddyono, 2012: 97) that local wisdom is a form of knowledges, believes, understandings, or the ideas about customs or ethics that guide human behavior life. We can see this very clearly and honestly when we see how the citizens participate in the delivery of information on the topic of regional, cultural, or even an information about natural disasters. The local communities as part of the local residents and witness can proclaim that information in a real place is match situation without exaggeration-as happened in the mainstream media in Indonesia. It then makes citizen journalism as a form of active participation of citizens in rescuing the culture and local wisdom.

\section{Research Methode}

This paper is using the focus group discussion to the university students who are have an interesting in journalism field as well as in depth intervies to them who are work on the journalism practise and academic field. That are four groups that 
had been work on focus group and four persons who are part of the respondents that work on journalism practice and academic field.

In those qualitative method, the writer was asked about some topics, such as: the present of citizen journalism; their opinion and reception to the citizen participatory; their opinion about local wisdom which brough on citizen journalism; and how citizen journalism works in the information era as well as society.

\section{Finding and Discussion}

\section{The Respondents Perception Review to Citizen Journalism}

After having the focus group to the respondents, the writer got some data about their perception of citizen journalism and how citizen journalism is representation of local wisdom in the information era. The majority of the groups perceived that citizen journalism is a kind of new way of journalism, including the story of local culture that are shared in blog aor social media. They perceived that citizen journalism is a way out form the previous journalism which produced by professional journalism worked by maintream news media. Otherwise, some of other groups still can not fully agree that citizen journalism is part of journalism. The minor group said that it because of the lack of accuracy and lack ability of the citizen on reporting the information. They also persume that the content of citizen journalism sometimes does not kind of populer issue, therefore they tend to choose mainstream media to get the current popular issues.

Those results has difference findings on other groups who perceive that citizen journalism is part of alternative news or information in this inforamation era. These groups tipically those who are have a sceptic looks to maintream news media, in which they think that Indonesian mainstream media nowadays tend to the political interest of their owner. These people saw that by the merger of some television make the news are no more objective. It is become worse since some of the owner of the media institution affiliated to the political parties or even become a legislative candidates from those parties.

Meanwhile, these groups also part of them who also actively involve in journalism fields, therefore they really feel that Indonesian nowadays news are effected by many interest. These people persume that citizen jorunalism could be the medium of alternative in the way of people collect and selected the information which they want to consume. They give an example about the information of natural disaster that reporteed by citizen journalist. In their consideration, citizen journalism able to represent the citizen to speak up their need when disaster comes. 
The respondents said that as a part of victims or eyewitness, citizen bring the issue in the right context and will not over reported as maintream news media does. These group also including the people who work on academic field as well as researchers.

They have same way of opinion on percieve about the role of citizen journalism in the information era. Somehow it might not be as good as the visualization or how the content well concept as mainstream news media does, but in their arguments it brings something that mainstream media does not have and does not offer to the people or local society. The pessimistic also arised from them as mainstream media always be buzy with their own interst without and leaving how its be beneficial to the society.

This pesimistic also shown on how the groups' perception about the "use" of citizen journalism in maintream news media as a bait cooperation to drive more audience to watch and use the media. Political issue arised since the tendency of the mainstream news media seems like did not maintain every program which collaborated with ctizen journalists, for example "Wide Shot" in MetroTV and Citizen Journslism Liputan 6 in SCTV (Indonesian television).

Citizen journalism considered as the way out of the political, interest routine, and agenda setting of the stakeholder power. By citizen participation, some of respondents said that it could be bring the new athmosphere and bring out the local context to the air. The citizen correspondency also percived on how society also controll the mainstream media on inform the people. At last, some respondents also noted that it can be the rise of Indonesian society in promoting and educating its own citizens. Through maintaing the local wisdom by participation to citizen journalism is regarded as a real activity which society as if it were forced to react to events, especially the local events that occur in the vicinity. Expectations of this activities are they aware and able to respond to the current issue or local issue which then could develop and educate themself.

\section{Citizen Journalism as Representation of Local Wisdom in the Information Era}

As we read in the findings resume above, there are some points that become consideration of the writer to be discussed. The first is about the contradiction that still embeded in disscussing citizen journalism. The posisition in which people still can not perceive citizen journalism as part of journalism in a new way which vise versa to them who are have a positivistic perceiption. As we know that we have-let we say-old journlism and new one. The old journalism are populer by their concept 
of $5 \mathrm{~W}+1 \mathrm{H}$ and always uphold objectivity and obvious facts. Nurudin (2009: 180) wrote that by the changing of technology and way of audiences or users consume the information, it definetly change on the way of people inform and produce the news. The technology nowadays drives people to read many sources of issues, and by this condition, the "flooded" information which are shared by people and institutions should have interest point to be "pick up" as a reading to the users. It then brings journalism into a form of changing way of it is spoken or in the narrative way. Nurudin explains more that this tendency are whithout leaving the role of journalism by its upholding facts. Moreoever we can see it at the information that are offerd by citizen journalists. Some of them are create their reportage or information by a unique narative which had been avoid by the "old" journalism etics.

Second issue is about the role of citizen journalism as an alternative media information from maintream news media. The respondents was gave an example of how the citizen journlist as the eyewitness able to be a representative of the local people situation and be honest on its reporting. Muzayin Nazaruddin as one of the respondent who work as a researcher in disaster journlism field was quoted Edwin Jurriens (2014) who said that alternative media, including citizen journalism based media, have positive contributions to disaster relief and community resilience. This strong positive contribution comes from their close relations and sensitive understanding to the people who directly affected by the disaster. As it is also reflected in the finding of Dewi research about reception of citizen journalism (2013) that majority the respondent have hegemonic dominant position on recept the news or information from citizzen journalism in the natural disaster topic. By that research some respondent consider the same as this paper respondents did. They percived that citizen journalist is more honest on the reporting about the natural disaster hapening, it because of they able to report as what happen to them in thereal condition.

The second issue above also can be represent on how citizen journalism able and represent the need of local people. It is then can be represent of the local wisdom that is include in the reportage of citizen journlists. The citizen as the one who considered as an interest and political free. As Dewi (2015 quoted from Hermawan 2009) wrote that information that produced in the mainstream media are oftenly can not separated from the needs and interest. of stakehoders and capital institutions. Moreover Hermawan (2006: 11) said that sometimes mainstream media can should be carefull on writing the news, because they might be reported more than irt should be. This is then be overtaken by the emerge and the existance of citizen journalism. Citizen journalism has a point that can not be buy by the mainstream news media. It has "proximity" as the 
major factor on representing the local feelings, needs and real athmosphere on how it is reported and how local wisdom brought to their reportage. The existance and feels of local wisdom is become the basic neds of the reception of the society on accessing information. Some scholars argue that people have tendency on collecting the information which are arise and about the closer place to them. It is inline with (Istuyanto, 2012) which percieved that local wisdom are really become the basic and foundamentally factors of the local people. He added that it also can be gateaway from foreign cultural which are now are easily come and addopted to the people.

Information era cannot keep each nation and cultural away from the foreign or western cultural effect. As Istiyanto (2012) argues that at the previos time, we can counting the media, and the producer of information are seen, but nowadays we even can not know who is the producer of information content. As regard that nowadays audience are active so that they are have their own moevement on sellect, produce, sharing and using the information based on their capasities (Dewi 2013).

Therefore, by maintaining the participation of people to this activity, citizen journalism can be answered as the last issue in this paper. It can show us how it can create a new way of local society educate its own people. The respondents in this reasearch perceived that citizen journalism has ability to improve and educate its own society. The chance of participation giving space to the society to join to citizen journalism activities. People can produce or even give an opinion or feedback about an issue which arise in their society. By this habit, people then could develope their self to be more critic to the situation. It is also can be use to build their local character as society. Eun Tak Hong (2006) as the head of editor in OhmyNews was quoted by Kurniawan (2007: 75) that the society are the last bastion of the information. Through this information era and the ofference users participation, bring them to the last squad on evaluating those information. The ability and critically thought that own by the people can be the measurements of the content of information. The lasted one, the finding shows that the respondents regard that citizen journalism is part of new journalism way which also contributes in making and conserves the local wisdom of a society.

\section{Conclussion}

The findings on this research shows us that there are three considerations which could grabbed from how citizen journalism is a kind of representation of local wisdom in information era. The first one is about the contradiction that still embedded on perceiving citizen journalism. Some people still perceived 
that citizen journalism is "a grey part" of new journalism. It is beacuse of its way of it is collected and reported which somehow lack of accuracy and less professional compared to the mainstream media news. The second is that eventhough some people still have less trust of this kind of information, but they think that citizen journalism can be alternative media information which brings local context far from the the capital interest. Meanwhile, it then drives people perception than citizen journalism is part of activity which can educate its people and conserves the local wisdom by let its society involved in this activity, when it done in a proper way. The people think that if society have these kind of habit-the news that made, diseminated and consumed by its own people-then it can drives people on trying to do better and trusted, which it is part of educating the people itself.

\section{References}

Athique, Adrian. 2013. Digital Media and Society: An Introduction. Cambrigde: Polity Press.

Budyatna, Muhammad. 2005. Jurnalistik. Teori dan Praktik. Bandung: Rosdakarya.

Carah, Nicholas and Louw, Eric. 2015. Media and Society: Production, Cotent and Participation. London: Sage Publications.

Haryanto, Ignatius. 2002. Jurnalisme Era Digital: Tantangan Industri Media Abad 21. Jakarta: Kompas Penerbit Buku.

Lister, Martin. Etc. 2003. New Media: A Critical Introduction. Canada: Routledge.

Lull,James. 2007. Culture on Demand: Communication In Crisis World. Oxford: Blackwell Publishing.

Nurudin. 2009. Jurnalisme Masa Kini. Jakarta: Rajawali Pers.
Citizen Journalism Peluang Dan

Tantangannya, accessed from: http://repository.ui.ac.id/contents/k oleksi/2/1b3820f2e51a8597b3c5aaa 78969doe746a5fbd7.pdf (MAKARA, SOSIAL HUMANIORA, VOL. 11, NO. 2, DESEMBER 2007: 71-78 71 JURNALISME WARGA DI INDONESIA, PROSPEK DAN TANTANGANNYA Moch. Nunung Kurniawan The Jakarta Post, Jakarta 10270, Indonesia E-mail: iwwan@thejakartapost.com)

\section{Media komunitas dan Jurnalisme} Lingkungan, accessed from: http://komunikasi.unsoed.ac.id/site s/default/files/o7.Aryo\%20Subarka h\%20-\%20univ\%20Bakrie o.pdf (MEDIA KOMUNITAS DAN JURNALISME LINGKUNGAN BERBASIS KEARIFAN LOKAL (Studi pada Situs www.suarakomunitas.net dalam Pemberitaan Isu-isu Perubahan Iklim) Oleh: ARYO SUBARKAH EDDYONO, S.Sos. M.Si.1 Dosen Ilmu Komunikasi di Universitas Bakrie - Jakarta Jl. HR. Rasuna Said Kav. C-22 Kuningan, Jakarta Selatan - 12920. HP: 0818467664, E-mail: arieseus@yahoo.com) 
Keberhasilan Citizen Journalism Membangun Kearifan Lokal, accessed from:

http://komunikasi.unsoed.ac.id/site s/default/files/og.bekti\%2oistiyanto -unsoed-final.pdf (KEBERHASILAN CITIZEN JOURNALISM DALAM PEMBANGUNAN BERBASIS KEARIFAN LOKAL S. Bekti Istiyanto)

Peluang Dan Tantangan Bangun Media Basis Kearifan Lokal, accessed from: http://komunikasi.unsoed.ac.id/site s/default/files/15.DEDEHFARDIAH unisba.pdf (PELUANG DAN TANTANGAN MEMBANGUN MEDIA PENYIARAN BERBASIS KEARIFAN LOKAL DI JAWA BARAT Dr.Dedeh Fardiah,M.SiFIKOM UNISBA (o8122333753) : dedehfardiah@gmail.com)
Strategi Mengemas Identitas Lokal, accessed from:

http://komunikasi.unsoed.ac.id/site s/default/files/65.STRATEGI\%20M ENGEMAS\%2OIDENTITAS\%20LOK AL\%20DALAM\%20PENGEMBANG AN\%20TV\%20LOKAL.pdf (STRATEGI MENGEMAS IDENTITAS LOKAL DALAM PENGEMBANGAN TV LOKAL Tri Nugroho Adi)

TV Lokal Strategi Kreatif, accessed from: http://unmermadiun.ac.id/repositor $\mathrm{y}$ jurnal penelitian/Jurnal\%20Sosi al/Jurnal\%20Sosial\%202013/Septe mber/3 Nunik\%2oHariyani hal\%2 023-36.pdf (TELEVISI LOKAL DALAM PERENCANAAN STRATEGI KREATIF PROGRAM BERBASIS “LOKALITAS” SEBAGAI WUJUD EKSISTENSI MEDIA Nunik Hariyani 1) 1) Dosen Fakultas Ilmu Sosial Dan Ilmu Politik Universitas Merdeka Madiun email : hariyaninunik@yahoo.com) 